\title{
The Berenson Collection: A Guide
}

\section{Citation}

Connors, Joseph. 2016. The Berenson Collection: A Guide. I Tatti Studies in the Italian Renaissance 19, no. 2: 235-255. doi:10.1086/688511.

\section{Published Version}

$10.1086 / 688511$

\section{Permanent link}

http://nrs.harvard.edu/urn-3:HUL.InstRepos:34614373

\section{Terms of Use}

This article was downloaded from Harvard University's DASH repository, and is made available under the terms and conditions applicable to Open Access Policy Articles, as set forth at http:// nrs.harvard.edu/urn-3:HUL.InstRepos:dash.current.terms-of-use\#OAP

\section{Share Your Story}

The Harvard community has made this article openly available.

Please share how this access benefits you. Submit a story.

Accessibility 
Joseph Connors, "The Berenson Collection: A Guide," in I Tatti Studies, 19.2, 2016, pp. 235-55.

Review essay on The Bernard and Mary Berenson Collection of European Paintings at I Tatti, edited by Carl Brandon Strehlke and Machtelt Brüggen Israëls, Florence: Villa I Tatti and Milan: Officina Libraria, 2015

A decade in the making, ten pounds in weight and eight hundred pages in length, the catalogue of the Berenson collection is finally out. That this is an exceptionally beautiful book with superb color illustrations and elegant layout and typography will be evident to anyone who takes it in hand. Forty-five authors, from the senior statesmen of Renaissance art to a new generation of scholars, wrote entries on one hundred and ten older paintings in addition to thirty-nine works by the Berensons' contemporaries and related material, both real and fake. ${ }^{1} \mathrm{~A}$ bibliography of three thousand items is joined with research in the archives of dozens of museums, collectors and dealers, not least those at I Tatti. Erudition on this scale in a single tome is rare. The book is an Alp.

The downside of weightiness is that the catalogue risks sitting on the shelf, admired by all but consulted only by specialists. This would be sad since it is surprisingly readable and has exciting material. My aim here is to offer a guide for the curious. The book took me a month to read it but it can be delved into with profit even for a spare half hour here and there or a summer's afternoon. Visitors who are impressed with the general atmosphere of the house but confused by the dozens of unfamiliar artists' names can use it to put order into their impressions. In particular, I want to show fellows at the Harvard Center who will be living with the collection for an extended period how to use the book. It does not have to be read cover to cover but it is habit-forming once you get into it. If rightly handled it offers pathways into early Renaissance art, the history of connoisseurship, and the formation of the collection that no amount of clicking could ever afford.

The book is easy to navigate and for that reason I refrain from all but a minimum of footnotes to it. The entries on the artists take up the central five hundred pages. They are in alphabetical order (often by first name) and it will not be hard to locate the quotations and facts I mention below. Although I will treat them last the catalogue opens with three general essays: one by Carl Strehlke on the formation of the collection, a second by Machtelt Brüggen Israëls on the role of Siena, and a third by Giovanni Pagliarulo on photography at I Tatti. After the catalogue entries come sections on the counterfeits and on art by the Berensons' friends and 
contemporaries. At the end there is an appendix on a hundred and one paintings that are known to have passed through I Tatti to other owners.

Before getting to the masterpieces, let me mention two features of the catalogue that the general reader should know about even if they are meant for the specialist.

First, condition. Each painting was taken down and examined intensely by eye followed by technical examinations with equipment loaned by the laboratories of the Opificio delle Pietre Dure. One of the photographs brings back a vivid memory of the day when cushions from the living room couch were laid on the floor in case a tall panel under examination should fall over. Most of paintings are on panel and these sections offer a succinct, high-level course on wood and tempera technique in the fourteenth and fifteenth centuries. Such analysis can be crucial in decisions about the placement of a panel in a larger polyptych. Scholars can tell whether a panel has been cut down or inserted into a foreign context. Technique sometimes arrives on a white charger to put an end to debate, as in the case of the severe St. Anthony Abbot who scolds otherwise happy visitors descending the staircase. It had been bounced from the oeuvre of Orcagna (Mary Berensonbut finally a scientific analysis of the punchmarks in the gold ground brought it firmly into the camp of an obscure painter, Giovanni di Bartolomeo Cristiani.

Old photographs are essential in documenting condition and the Berensons turned themselves into assiduous collectors of photographs, as anyone who has used the Fototeca knows. The essay by Giovanni Pagliarulo traces the photographers working for the Berensonsas of 1910, especially Harry Burton, who would achieve world fame in 1922 when he photographed the tomb of King Tutankhamun for Howard Carter and Lord Carnarvon. The essay traces the history of photographic technique through prints and negatives in the collection: early albumen, carbon and gelatin silver prints, even the fascinating interlude (1907-35) of autochromes by the Brothers Lumière that presage color photography. A poetic final paragraphs links changing techniques in photography to a succession of movements in twentiethcentury art. $^{2}$

Second, biography. Each artist is given a compact biography based on new research. For the famous painters this is likely to be the best short biography available and for many lesser artists likely to be the only biography in English. The bonus of the way the catalogue is planned is that even minor works in the collection trigger substantial biographies, useful far beyond the scope of the book. For example, while Perugino is represented in the house by two small embroideries, the biography includes not only the known facts of his life, clearly and succinctly presented, but 
the historiography of his reputation. The Sano di Pietro biography is the first to synthesize the new consensus, developing since documentary finds of 2012, that the famous Osservanza master, whose oeuvre was assembled over the past sixty years, is really the young Sano. To go with a small double-sided Madonna by the famous Pietro Lorenzetti we are given a life that charts the art and movements of this complex painter. And the Madonna, whose "calm expression and majesty do notexclude tenderness," is traced back to its original home in the Augustinian monastery of Lecceto near Siena.

Biography is one thing for Vasari-level artists, but another for late medieval and early Renaissance painters about whom we have scant dates and little personal information. Such artists become their oeuvres. It often takes generations of scholarship to construct a personality in these conditions. In the vita of the Sienese Trecento painter Bartolomeo Bulgarini, for example, the catalogue takes us on a historiographical journey that begins in the early twentieth century with a construct called "Ugolino Lorenzetti" because the oeuvre smacked of both Ugolino di Nerio and Pietro Lorenzetti, through a phase when the painter was called the Master of Ovile, to the 1930s when the real name emerged from the archives. Such is the origin story of one of the few Sienese artists to come from the nobility. The biography of Bernardo Daddi has to cope with the whole spectrum of response to this most prolific of painters, from Berenson's charge of mere prettiness through Longhi's "delightful yet mediocre songbird" to Offner's "pushing refinement to Keatsian limits." This is followed by a daring reconstruction of the altarpiece from which the Berenson Daddi came.

Never lone geniuses in this period, artists came out of workshops with complex hierarchies and specializations. The biography of the Trecento Cione family is a lens onto a type of organization that takes giant strides with this family and will have farreaching consequences into the fifteenth century. The collection has works attributed to both Gentile and Giovanni Bellini and the pair of vite in the catalogue make it easy to jump into the extensive literature on the most important artistic family of Renaissance Venice. Giovanni's Madonna, thought to be a fake by its first restorer, then glorified by Berenson only to be ruined in the war, has now found a peaceful resting place as studio of Bellini, possibly the young Marco Basaiti. In other words, not a painting to make a pilgrimage to Fiesole for. On the other hand, the catalogue restores to Gentile the lovely Madonna and Child (with the charming bird on a string) in the small dining room and charts in a new way the relationship of early Gentile to his brother-in-law Mantegna. 
In short, if you need the biography of any of the Italian primitives or early Renaissance masters cross your fingers and hope that at least a fragment of his oeuvre is represented in the Berenson collection. The accompanying biography will not disappoint.

\section{Masterpieces}

Most readers familiar with the house will turn to the entries on Giotto, Domenico Veneziano, Lorenzo Lotto and Luca Signorelli. The research here is entirely new and the finds can be stunning. Previous owners had strong feelings about these works and the entries include a history of ownership and of appreciation in the midst of fluctuating attributions. These entries are compressed masterpieces of modern scholarship that one wants to recommend to art historians of any period and humanists in any field.

The living room on the piano nobile, once Berenson's study, has two Giottos. Carl Strehlke explains why the panel with a Franciscan saint, here identified as St. Anthony of Padua, must come early in the master's career, why he is halo-less and how the panel fit into a larger construction, possibly a triptych with lost panels showing St. Francis and the Virgin. The other Giotto in the room, the small Entombment hanging against the window wall, is placed later, about 1320 (Fig. 1). I found it fascinating to follow the clue-gathering process which resulted in a reconstruction and a history. The original altarpiece may have been as big as seven panels in a row with five more on top. Painted in Florence by the workshop with final touches by the master, it was sent abroad, possibly to Rimini. There the cramped and halo-less figure of Nicodemus would have been added on arrival at the behest of the patron, a surprising deduction that makes us take a hard second look. The entry is especially poignant for anyone who has felt the magic radiated by the picture in the evening with the gold ground glowing while the figures slip into the penumbra. It is the entry to carry with one (how nice a web version would be!) when one sees the other panels from this famous altarpiece in the Metropolitan Museum, the Gardner, the National Gallery in London and the Alte Pinakothek in Munich.

The Giotto biography accompanying the two entries is the best short account one can find of the life and reputation of this peripatetic master. It puts the great tropes (like Dante's "Ora ha Giotto il grido") into context and gives the historiography of the Giotto/non-Giotto question for the frescoes at Assisi. The conclusion that Giotto was like a master designer who sets up workshops and returns from time to time to oversee huge decorative projects puts questions of attribution into a new light. 
The Domenico Veneziano Madonna and Child has always hung in the study/living room (Fig. 2). This great painter, who signs himself elsewhere "da Venesia" though we really know nothing about his origins, emerged in Perugia around 1438. After he arrived in Florence he was somehow a formative influence on the young Piero della Francesca. Together they participated in one of the most important decorative enterprises of the Florentine Renaissance, the Portinari Chapel in Sant' Egidio at the hospital of Santa Maria Nuova, now sadly lost. The Berensons acquired the painting in 1900 from the Marchesa Marianna Paulucci Panciatichi Ximenes d'Aragona, a distinguished naturalist whose famous orientalist father had rebuilt the family castle at Sammezzano in rural Tuscany into a gigantic example of the Moorish revival with different orientalizing décor in each of the 365 rooms. When word of the sale (as a Piero della Francesca) got out officials at the Uffizi tried to block it but had to settle for a deal that gave the family half of the profit should the painting ever be sold. Once they got it to their new home the Berensons resisted attributions both to Piero and to Domenico Veneziano and for decades stuck with a lesser light, Baldovinetti. Finally around 1930 Domenico's great St. Lucy altarpiece in the Uffizi was united with its predella panels and the artist's elusive personality began to come into focus. By 1932 Berenson had come round to the attribution.

In post-Berenson scholarship the problem moved from attribution to date: early, with all that gilt and brocade, or late, with that perfection of form and subtle play on natural and divine light? The weight of opinion is now with late. The authors, Caroline Elam with Carl Strehlke, offer two tempting suggestions for patronage: Marco Parenti with his taste for fine silk, or someone in the Peruzzi clan who would have liked the little pears the Madonna holds. It is nice to know about both pears and silk but on the deepest level this unforgettable painting holds us riveted by the simultaneously perfect and warm-hearted protagonists, the Madonna and her Child, "a human relationship conscious of divine responsibility."

Lorenzo Lotto was the subject of Berenson's first book but the small Lotto Crucifixion resting on the bookshelves of the Signorelli corridor was the last painting to enter the house as a gift from the dealer Alessandro Contini Bonacossi in 1953 (Fig. 3). A note on the back by Lotto's friend Giovanni del Coro tells us that the artist painted it at Loreto in Holy Week of 1544, timing his work to finish at 3.00 p.m. on Good Friday, the moment of Christ's expiration. Technical examination helps us understand the magic by which Lotto made the arma Christi emerge from the blackness swirling around the crucified Christ. Lotto had a copper case made for the painting perhaps to protect it during travel. The entry by Charles Dempsey with Carl Strehlke probes the liturgy of the Good Friday mass and the iconography of the 
Vision of St. Gregory to show how Lotto appropriates elements of the papal vision "per sua devotione."

The Signorelli Gallery was built as a corridor to connect the house with the library. The library door is usually closed and the dead-end gallery has become a place for displaying Berenson's collection of oriental art plus a few Renaissance paintings, including the Lotto, the repainted wreck of a Giovanni Bellini studio Madonna, and the portraits by Luca Signorelli that give it its name. The latter occasion a fine biography of one of the most important painters of the Renaissance. In the accompanying entry on the portraits of the brothers Vitellozzo and Camillo Vitelli by the co-editors we learn much about this ill-starred military family from Città di Castello, whose violent deaths stain the pages of Machiavelli, Guicciardini and Paolo Giovio. Commissioned as posthumous commemorations the portraits came from the Giovio collection, possibly painted when Giovio was still amassing his collection in Florence. Certainly they were jewels among the 394 portraits assembled in Giovio's famous museum on the Lake of Como, copies of which now line the ceilings of the Uffizi. Since the portraits were bought in London Bernard and Mary fumed when a law of 1909 threatened to notify them, thus precluding export. A third Vitelli portrait stayed in England and is now in Birmingham. All three are compared in the catalogue with the woodcuts made after them for Giovio's Elogia virorum bellica virtute illustrium of 1575. One of my most vivid memories from I Tatti is of the Berenson copy of this book being brought from the vault into the Signorelli corridor and opened to the Vitelli woodcuts, proving the identity of the sitters and the provenance at the same time.

\section{Reconstruction of Altarpieces}

Many of the paintings are fragments of altarpieces dismembered in the century of depredation between Napoleon and the arrival of the mogul collectors. The Sassetta panels are the prime example, but there are dozens of smaller paintings which offer the opportunity to re-unite panels scattered all over Europe and America, re-insert them in their original context, and occasionally suggest a patron. When companion panels in other museums are known, they are given short entries of their own, a most helpful convention. This is where technical investigation is essential. The sawn edge of a panel, sometimes even a crack or a worm-hole can clinch a reconstruction of panels scattered over many museums. Often the Berenson collection will have a small fragment of a larger altarpiece; the catalogue takes the opportunity to study all the disiecta membra wherever they have landed.

For example, a small and not very eye-catching painting by Botticini, Marriage of the Virgin, becomes far more interesting once it is identified as part of the predella of 
the large altarpiece once in San Felice in Piazza, the church opposite and slightly south of Palazzo Pitti. This feat of sleuthing then leads to the assembly of the oeuvre of an artist who started at age fourteen and whose early work until now had been hard to discern. Another example is afforded by the two Gentile da Fabriano panels that sit on the cupboard under the Domenico Veneziano in the Berenson study/living room. Close examination of these very small paintings produced large results. On the back of one is a seventeenth-century copy of a 1408 inscription. First noticed in 1993 and here deciphered in full with the help of ultraviolet light, the inscription leads to Santa Sofia in Venice and the Sandei altar that once graced the church. Reconstruction is helped by the hypothesis that Pandolfo III Malatesta of Brescia commissioned it for Martin V to bring to Rome. The entry on the other Gentile painting, the much damaged but still exquisite Madonna and Child that hangs in the corridor outside the director's office, is not a reconstruction but it beautifully illumines one of Berenson's least expensive but choicest acquisitions.

The imposing altarpiece that hangs at the bottom of the stairs close to the small dining room is so large that Mary wondered whether her architect, Cecil Pinsent, would find a place to put it. It was formerly attributed to the Master of Palazzo Venezia or to Lippo Memmi but is here given to the brothers Lippo and Tederigo Memmi. Since the Master of Palazzo Venezia has sometimes been identified in the past with Tederigo, the joint attribution to both brothers cuts the knot in a convincing way. The reconstruction takes us rather far from Tuscany. Machtelt Brüggen Israëls has rediscovered a key passage in Suarès's seventeenth-century history of Avignon that allows a hypothesis to be framed, tentative at first but more and more convincing as the evidence piles up. We move to Avignon where the altarpiece would have been painted in the 1340s by the Memmi brothers on commission for the chapel of Napoleone Orsini in the church of the Cordeliers. A print is found that shows the pre-Revolutionary state of this church. A reconstruction is offered showing how the painting would have handled predella, piers and pinnacles, and the iconography is discussed in the context of the debates on evangelical poverty and the beatific vision swirling around figures like Ubertino da Casale. The excitement of discovery transpires in every line of this scintillating entry.

The most notable of the altarpiece reconstructions involves the three famous Sassetta panels. This is of course the subject of a vast, multi-authored research project published by I Tatti in 2009. Those results are re-presented in miniature, so to speak, by Machtelt Brüggen Israëls, the editor of the earlier book. The sixty or so panels of this huge altarpiece are put in their proper places on the basis of extensive physical and scientific examination, making it possible to deduce narrative strategy 
and aesthetic effect from the scientifically reconstructed painting rather than the other way around, as was done in previous interpretations.

The entry clearly spells out precedents for the unusual Franciscan iconography in an altarpiece by Taddeo di Bartolo now in Perugia, and in a Spinello Aretino altarpiece, now lost but, amazingly, reflected in an intarsia panel in a choir stall still in the church. The analysis is subtle: the Vices that frightened Dante at the opening of the Inferno are knocked flat by Franciscan Virtues, especially Lady Poverty and Obedience, so dear to the Osservanti patrons. The saint himself, Alter Angelicus and Alter Christus, made unearthly by a gilt mandorla of great pictorial delicacy, is illuminated by Franciscan writings. The acquisition and display of the paintings are put in the context of Berenson's appreciation of Buddhist spirituality. The "subtile ingenium" that the Franciscan patrons saw in Sassetta is matched by the subtlety and elegance of both entry and biography.

Visitors might remember a pair of worn-out looking panels near the head of the stairs showing the martyrdom of Sant'Apollonia (patron of dentists and toothaches) by Francesco Granacci, the artist who taught the young Michelangelo to paint. The catalogue traces them to the Florentine convent of that saint, for which Michelangelo did the front door. Interestingly, the scenes are based on a fifteenthcentury Florentine legendary on female martyrs rather than the more famous Golden Legend. This entry is one of several that rehabilitates paintings that suffered severe damage when the apartment of Alda von Anrep, Nicky Mariano's sister, was destroyed in the mining of houses along the Arno during the German retreat in August 1944.

Amidst the many reconstructions there is a surprising deconstruction as well. Most visitors to the house will remember the large pentaptych of four scowling saints and a Madonna that sits on the bookshelves near the top of the staircase. More than any other work it is the one that most makes the house feel like a sacristy. Berenson acquired it from the Toscanelli collection ca. 1908. The catalogue takes the whole thing apart and gives the panels to three separate painters: Bulgarini for the four saints at the sides, Niccolò di Segna for the central Virgin, and Pietro Lorenzetti for the small pinnacle over the Virgin. They were assembled in ca. 1883 from unrelated altarpieces by the restorer and furniture designer Gaetano Bianchi to enhance the sale of the Toscanelli collection. The figure in the pinnacle is now Christ, who holds a scroll that reads "Ego Sum Via Ver[it]as." But in an earlier life this was a mere saint. If you look closely at the scroll with a flashlight the original identity can just be made out: "S. Marci." The restorer-fabricators of the polyptych felt that a more august personage was needed to preside over their magnificent contraption. 


\section{Furniture}

Among the little noticed treasures of the house are some unusual pieces of furniture with art on them. More than painting, antique furniture went through the restoration studios in the nineteenth century and came out enhanced. Until preparation of the catalogue no one paid much attention to the cassone that stands under the Cima St. Sebastian near the director's office. It always seemed just an old wooden box enlivened by a talented restorer. A fascinating entry by Mattia Vinco shows that the roundels on the front were painted by Liberale da Verona. Aged and covered with grime the scenes seem illegible at first, but in the entry they are coaxed out of the darkness into wonderful depictions of Apollo's Pursuit of Daphne and the Marriage of Apollo and Daphne. That marriage should be the outcome of this notorious chase might seem strange, though Ovid intimates marriage and the verses called La Complainte del amant from Jean Frossart's L'Espinette amoreuse of ca. 1370 provide a source close to home. Here we have not only a new work by Liberale, but also the only cassone by his hand to survive intact: a complete surprise and a real discovery. It goes together beautifully with the entry by Keith Christiansen that shows that the other Liberale in the house, a small scene of young men looking at some unseen event, is also part of a cassone. When the pieces are put together it emerges that the men are looking at one of their number playing chess with a beautiful blond lady.

The entry on Francesco di Giorgio re-unites fragments of a broken-up spalliera of exceptional importance, now split between the Berenson and the Stibbert collections (Fig. 4). The Francesco di Giorgio hangs outside the director's office and as the work of an architect/painter I deeply loved it. I remember going to the Museo Stibbert with photographs to test the connection but coming away discouraged. The panels didn't seem to fit well together and the figures seemed to be on an entirely different scale. What I didn't realize is that the lower part of the Berenson panel had been cut away so that we are really seeing mid- or background figures, necessarily on a smaller scale than the protagonists in the Stibbert panel who occupy the foreground. And in the end the wood grain of the two panels lines up perfectly. A single panel had been sawn in two to increase its market value. But what had it originally shown? Marilena Caciorgna's fascinating entry shows that the subject had been the Rape of Helen, taken not from Homer but from a Trecento epic on the fall of Troy by Domenico da Monticchiello and Binduccio dello Scelto. She ties the panel to the opposite of a classical rape, a Renaissance wedding, specifically the UgurgieriUgolini wedding in 1491, a date concordant with Francesco di Giorgio's stylistic evolution. Humanistic culture, including knowledge of the medieval transmission of 
Homer and Homeric tales, and expert sleuthing come together in this fascinating piece.

\section{Connoisseurship}

The catalogue does not set out to prove that Berenson was always or even often right. ${ }^{3}$ Indeed, to read the entries is to learn that attribution is seldom a one-time lampo di genio by an all-knowing hierophant but rather a multi-generational affair, imprecise at first but gaining exactitude as the artistic personalities assume clear contours. Of course, the Berensons were thought to be good at it from the start and his name became obligatory on authentication certificates in the international art market. But for his own paintings he allowed himself many changes of mind. In the case of a Virgin of the Pomegranate with Four Angels, for example, Berenson started out with Sassetta and then moved down on the prestige charts to Pietro di Giovanni d'Ambrogio. Of another work by this artist Berenson claimed that it had taken him fifteen years to arrive at the final attribution. (Scholarship took many more to arrive at the current attribution to the next-to-unknown Jacopo Zabolino.) A Face of Christ that everyone agrees derives from Fra Angelico's Man of Sorrows has an interesting attributional journey from Andrea del Castagno to the obscure Biagio d'Antonio. The painting on the dust jacket of the catalogue, the St. Michael the Archangel Enthroned, made its way from the Dondi dell'Orologio collection in Padua through Jean-Paul Richter in London to I Tatti, where it was the Berensons' first purchase for their new home. On the way it changed from a Crivelli to a Giambono.

Attribution is often an agonistic pursuit. Berenson's worthiest rival in the field was Roberto Longhi, who appears often in the catalogue. He mapped out the still unchartered field of the Renaissance in Ferrara and the catalogue offers a vivid account of the splash his Officina ferrarese make when it appeared in 1931(212). The entries on a pair of small panels now flanking the Cima da Conegliano St. Sebastian let us see how Longhi went about fashioning a new personality in the 1930s, Vicino (i.e., close to Ercole De Roberti) da Ferrara. Thrusts and parries between rivals pepper many entries and Longhi never seems so happy as when he can subvert Berenson's attribution of an I Tatti painting. Berenson's treasured Ercole De Roberti Crucifixion was assigned to the lesser Lorenzo Costa by Longhi and the attribution has stuck (Fig. 5). No wonder that Longhi and Berenson stopped writing to each other after 1917. Still, it is touching to read the dedication Longhi wrote in the relevant volume of his complete works that he offered to Berenson in 1956: “A Bernardo Berenson - 'tanto nomini' - in segno di antica riconoscenza e di irrequieta ma continua fedeltà, Roberto Longhi." 4 
The dark Doppelgänger of connoisseurship is forgery. There is an illuminating section on counterfeits and catalogue entries for all that passed through Berenson's hands. It is interesting to read that the best of the fakes in the villa, the Madonna with Holy Innocents was done by the subtle Giuseppe Catani Chiti. Berenson admitted than he had been fooled, saying that "in his youth the phantasm of a Botticelli entrapped him" (652). Now it is seen by few since it hangs in the private suite that used to be Nicky Mariano's room. In a more public place it would easily deceive the unwary.

A notorious forger tested the Berensons' mettle for years and often found it wanting. Icilio Federico Joni, the Spider of Siena, set up an operation that was organized like a Renaissance family shop. Early in their careers as connoisseurs the Berensons were tricked by dealers offering these specious paintings. Mary put their suspicions in a nutshell: "As to beauty - they are lovely! But there are too many of them" (25). They finally confronted the forger-dealer-restorer in person. Distasteful as it was to be duped, their connoisseurship emerged stronger from the experience. Berenson considered such people "gifted antisocial offenders" (639) but kept a Joni Madonna in his study to remind him of how fallible he had been. His association with Joni lasted a surprisingly long time. In 1909, to clear the air, seemingly at Berenson's urging, Joni put on a one-man exhibition with fakes and genuine primitives in his collection side by side. It did not reform Joni, who went on forging. Berenson remained in contact with this "restorer" up to 1932, when Joni accused him in his autobiography of unsavory dealings. At least thirteen Joni's passed through Berenson's hands and two are still in the house.

In 2004 there was a grand Joni exhibition in Siena, curated by Gianni Mazzoni, the author of this part of the catalogue. ${ }^{5}$ Those of us who visited it were tempted to congratulate ourselves by denying, thanks to hindsight, that the forgeries of the great masters would have taken us in. But when it came to the primitives, like a Margaritone d'Arezzo, I had to admit that I would have fallen into the trap. The show was popular on the principle that everyone loves a forger except for his customers, and Joni's stock has accordingly risen. Shortly after the exhibition, on visiting a patrician villa in the Senese, I glimpsed what seemed like a grand Renaissance painting on a distant wall. I asked my hostess what it was. She replied, "Grandfather thought it was Botticelli. Father suspected it was a fake. Now we're hoping it's Joni." In case readers of this piece want to test their acumen, they might pay special attention to the Madonna and Child that hangs on the landing of the staircase. It is a very pretty thing, but it must have been a sad fragment until it came out of Joni's shop with sparkling new clothes, a halo and a headpiece in a pharaonic style. 
The first catalogue of the collection, commissioned by Berenson himself from Franco Russoli and published in 1962, three years after his death, was over-liberal with Berenson quotations. Sprinkled throughout the text they were meant as homage to the master, but at times it was difficult to understand the relevance to the painting at hand. For example, in the entry on the Cima St. Sebastian, which is of course a male nude, this is the quotation from Berenson:

His [Cima's] figures are severe and chaste but seldom morose, and occasionally they have quivering nostrils and mouths of surprising sensitiveness. I seem to recognize in his women a kinship to certain of ours, produced by generations of puritanic repression and selection and rebellion. ${ }^{6}$ The present work, scientific in tone, has fewer quotations but chooses them well. Of Bacchiacca we read, unforgettably, that he "makes a parade of his thefts, like a Fiji islander." Boccati's angels "will never grow up - they remain children." In the Lorenzo Monaco Virgin of Humility "the ecstasy of the Orcagnas had flowered from half-hidden shoots into a rapture that surpassed theirs." Signorelli's late style shows "masses in movement, conjoined and rippling like chain mail." Neroccio di Bartolomeo de' Landi was a painter of "subtle linearity and dream-like aestheticism...a Simone come to life again...with a quicker suggestion of freshness and joy."

\section{Twentieth-century artists}

Particularly in the first decade of the twentieth century Berenson felt the need to engage with the art of his own time. He bought a painting from Matisse but later gave it as a gift to Paul Karađorđević when the prince was forming a national museum in Belgrade; later he bought a Picasso ceramic plate. Though he mentioned Cézanne in one of his early books he missed the chance to collect him and so cannot compare with two other American expatriates living in Florence, Charles Loeser and Egisto Fabbri, who built up significant collections of the post-impressionist master in the first decade of the twentieth century. ${ }^{7}$

Caroline Elam's essay on Roger Fry, complemented by her entry on the desco da sposalizio painted by Fry as a belated wedding present for the Berensons in 1901, provides the opportunity for a sensitive re-evaluation of the major British critic of the early twentieth century (Fig. 6). Fry is essential to understanding the modern reception of post-Impressionism in general and Cézanne in particular. He began as a welcome guest of the Berensons, especially Mary. We learn much about a friendship turned to rivalry and soured by Berenson's irrational sense of ongoing grievance. The key to the development of Fry's thought, we discover, lies in his reviews of Berenson's books, which are explored here in detail. They let us see Fry's growing reluctance to excluding emotional impact and "intensified sensation" in the exercise 
of connoisseurship. At the end, Fry turns away from his earlier conviction about the interweaving of dramatic subject and form to embrace a purer strain of formalism. Earlier he had taken his distance from Berenson, while later he sought "to disentangle our reaction to pure form from our reaction to its implied associated ideas." I cannot think of any catalogue that has such a penetrating essay on the historiography of twentieth-century criticism.

The essay by Claudio Pizzorusso on the frescoes of René Piot in the library explores the special moment of 1909-11 when Berenson began to turn eastward, acquiring the Javanese Buddha head and visiting the great exhibition of Islamic art in Munich in 1910. "The tide of my interests is flowing fast and strong eastward...the Renaissance is no longer my north star." At the same time he was exploring the Parisian art scene, particularly the work of Matisse and the decorations in Gide's house at Auteuil. Piot seemed to Berenson to be the rejuvenator of Florentine fresco technique, the modern painter who could rival Baldovinetti and capture the Virgilian rhythms of the farms and vineyards around I Tatti. The essay offers a fascinating new key to Berenson's turn to the exotic at just this time: the passionate affair with "Malayan" Belle Greene. When Berenson was with her at I Tatti he approved of Piot's frescoes even though Mary hated them ("awful," "revolting," "ghastly"); after the break with Belle he came back to Mary in heart and taste. The essay is a subtle analysis of the complex strands interweaving in French modernism around 1910 and its reception, then rejection, by a great critic.

\section{General Essays on the Berensons and the Collection}

I have saved the best for the end, namely, the essays by the two author-editors on the Berensons themselves and the formation of the collection. Anyone who wants to know I Tatti in depth should read them. Carl Strehlke brings up many unknown details from the couple's first decade of companionship in the 1890s: the importance of Milan as the center of Italian connoisseurship, the hunt for Lotto in the Lombard valleys and the Marches, even the role of Venice in a brief period of infatuation with the eighteenth century, which left its mark on two pockets of rococo taste in the house, the Ritz and the small dining room. The signature hang of the I Tatti pictures against backdrops of precious fabrics is traced to this early period in an informative section on fabric collecting in modern Italy. It is quite amazing to watch Strehlke tease the names and styles of the brocades out of an 1898 photo of Berenson seated on an old armchair.

When the couple first met and fell in love neither were collectors. A few small finds in the 1890s and Berenson's role as intermediary in purchases for Isabella Stewart Gardner helped lay the groundwork. But it was the move into I Tatti at the time of 
their marriage in 1900 that turned the Berensons into a collecting couple. The passion for ownership lasted over two decades. It got off to a resounding start when the Domenico Veneziano Madonna (as Baldovinetti), the Giambono St. Michael and the Sassettas entered their new home at almost the same time. The sums spent on art in the early 1900s are astounding, often amounting to many times the rent of I Tatti (2000 lire a year between 1901 and 1907) on a single purchase. For example, the marble Bindo Altoviti now hidden in the ivy over a fountain on the azalea terrace, which is somehow a version of the famous bronze bust in the Gardner Museum, cost over fifteen times the annual rent. An arrangement with the dealer Duveen (a 10\% commission in 1908, raised to 25\% in 1912) allowed an expansion and redecoration of the house and layout of the formal garden. This is also the period of Berenson's purchase of Chinese and southeast Asian art, usually from Paris dealers. For Bernard the link between Buddhist and Franciscan spirituality seen especially in Sassetta and the Sienese school was deeply meaningful. ${ }^{8}$ The First World War brought collecting on a grand scale to a halt. The last purchase was the Ercole De Roberti (now Costa) Crucifixion in 1922.

Strehlke follows the fortunes of the house through the Fascist period and the Second World War when it was expropriated but the collection not removed, the Nazi period in 1943-44 when Berenson was in hiding, and the post-war boom when Berenson became an international celebrity. It is fascinating to see Berenson envying revival styles of interior decoration but then resisting them. I Tatti was, on the contrary, the essence of the unfashionable. But it expressed the sense of adventure of an aesthetically minded couple in the springtime of connoisseurship when giving names to masters gave them as much pleasure as Adam and Eve had naming the animals in Paradise.

Machtelt Brüggen Israëls's essay explores the role of Siena in the connoisseurship and collecting of the couple. In the 1890s Siena and the Senese were essential to their world-view, although it was Bernard at first who moved about the rural countryside on donkeys and in horse-drawn carts and later by slow train. Siena when he first saw it was a town that closed its gates at night. He saw landscape through the eyes of the Sienese painters (to which Mary would add Monet). A visit to the abbey of Monte Oliveto Maggiore in 1891 led to a conversion to Catholicism, temporary of course. The Sienese school would become the largest of the Italian schools in the house, furnishing a third of the pictures.

The essay explores the bumpy, rivalry-ridden rediscovery of an art as unknown, they felt, as the cave paintings of Altamira. In the couple's endless "connoshing" in the towns and countryside of the Senese there were friends who opened doors and 
shared documents, like Frederick Mason Perkins; enemies, like Robert Langton Douglas, who tried to claim priority in the rediscovery of Sassetta; and forgers like Joni. Berenson was worried about the fate of Siena during World War II though it was in fact Florence which suffered more. Berenson disapproved of what we now think of as forward-looking art history, especially Millard Meiss's book on painting in Florence and Siena after the Black Death. Instead it was "soft Siena...sorceress and queen among Italian cities" that created the life-enhancing art for which I Tatti was meant to be the ideal home.

Both these essays and many of the entries restore the role that Mary Berenson had in the formation of the collection. She is justly remembered in the title. In their last decades the couple had drifted apart. Nicky Mariano made a more congenial companion and eventually a sympathetic biographer. She and Mary would team up when a more dangerous rival appeared on the scene, like the exotic Belle da Costa Greene, but Mary was left in the villa as an invalid when Nicky and Bernard went into hiding in 1943. When Mary died in March 1945, after the liberation of Florence and the return of many of the hidden paintings to I Tatti, Bernard could not bring himself to mourn her deeply. In his opinion she cared over-much for her family and resisted his plans to make I Tatti into an institute under the aegis of Harvard. Yet, in moments of reflection in old age, he admitted that whatever they had accomplished it had been as a couple:

She and I were pioneers, and our attributions have become part of arthistorical pooled capital. Our followers can only glean after us, or borrow under, metaphycize, iconograflate, rhetoricize the material, but we were among the very few who fished the murex up (35).

The catalogue is a mare magnum, but it is my hope that with a portolan in hand readers who have been moved by I Tatti or are interested in early Renaissance art or the history of art history might be tempted into venturing out on it. 
${ }^{1}$ The two author/editors came to the task with pertinent qualifications. One was the author of what is recognized as the finest catalogue of a permanent collection in an American museum: Carl Brandon Strehlke, Italian Paintings 1250-1450: John G. Johnson Collection and the Philadelphia Museum of Art (Philadelphia, 2004.) The Johnson catalogue is the template on which the I Tatti catalogue is based and also includes information on condition and a short biography for each artist. The other was the author/organizer of an international research project on the Sassetta panels at I Tatti and around the world: Machtelt Israëls, Sassetta: The Borgo San Sepolcro Altarpiece, 2 vols. (Florence and Leiden, 2009). Each wrote somewhat more than a third of the present catalogue with the final third the work of invited experts.

${ }^{2}$ The past five years have seen a movement to reevaluate the role of photographic archives such as I Tatti's. See Costanza Caraffa, ed., Photo Archives and the Photographic Memory of Art History (Berlin and Munich, 2011) and Costanza Caraffa, Tiziana Serena, eds., Photo Archives and the Idea of Nation (Berlin, 2015).

${ }^{3}$ In an interesting review Gary Schwartz gives Berenson a decidely low score, though on the premise that a connoisseur should be right on the first try: "Schwartzlist 345. The Transparent Connoisseur 4: A Berenson Scorecard," https://garyschwartzarthistorian.com/2016/03/28/345-the-transparentconnoisseur-4-a-berenson-scorecard (accessed 2016/07/08). ${ }^{4}$ Catalogue, p. 212: "To Bernard Berenson, 'the much celebrated,' in commemoration of long-held gratitude and of restless but continual faithfulness. Roberto Longhi." Wikipedia reminds us that "Tanto nomini nullum par elogium" is the epitaph on the monument erected to Niccolò Machiavelli in Santa Croce in 1787. ${ }^{5}$ Gianni Mazzoni, Falsi d'autore: Icilio Federico Joni e la cultura del falso tra Otto e Novecento (exhib. cat.: Siena, Santa Maria della Scala) (Siena, 2004). 
${ }^{6}$ Franco Russoli, La raccolta Berenson, with a preface by Nicky Mariano, Milan: Officine Grafiche, 1962; The Berenson Collection, translation by Frances and Sidney Alexander (Milan, 1964), LXXVI. This too is a weighty book. In fact, the combined weight of the Russoli catalogue, the present catalogue and the Sassetta volumes is thirty-five pounds.

${ }^{7}$ Francesca Bardazzi, ed., Cézanne a Firenze: Due collezionisti e la mostra dell'Impressionismo del 1910, (ex. cat., Florence: Palazzo Strozzi) (Milan, 2007). ${ }^{8}$ Carl Brandon Strehlke pursues the role of Asian art at I Tatti further in a pair of key articles: "Berenson, Sassetta, and Asian Art," in Israëls, Sassetta, pp. 37-49, and

"Bernard Berenson and Asian Art," in Joseph Connors, Louis Waldman, eds., Bernard Berenson: Formation and Heritage (Florence, 2014), 207-29. An overview of Berenson scholarship since his death in 1959 can be found in this volume. 